\title{
Homelessness in Romania - Challenges for Research and Policy
}

\author{
Cosmin Briciu \\ Research Institute for Quality of Life, Romanian Academia \\ cosminbriciu@gmail.com
}

DOI:10.5901/mjss.2014.v5n22p504

Abstract

The paper is dedicated to the analysis of homelessness in Romania, in its transformations during transition, as well as the dynamic of the set up aiming to tackle it. The wider context of the analysis is twofold: (i) for comparative purposes, the problem of homelessness worldwide is mainly addressed at the level of measurement methods and policies; innovative measurement techniques and programs implemented overseas are mentioned, in order to understand how the Romanian policies and research compare, and to highlight the range of development opportunities ahead; (ii) the various factors contributing to the occurrence of the social problem are put under scrutiny; homelessness is approached as a structural failure of the society, i.e. an extreme limit of the social inclusion and social development strategy, rather than an individual rebuff. The paper offers an understanding of the factors shaping life trajectories of homeless people. Researches show that family events play a prominent role (divorce, separation, eviction by the household members). The loss or inability to procure a dwelling (as in the case of youth exiting the social protection system) represents also crucial personal event, with a major explanatory role for homelessness. These factors are far more important than poverty per se, as many of the studies show. The paper profiles the multidimensional nature of the social exclusion of the homeless: lack of adequate and sufficient food, repeated sexual, physical and psychological abuses, chronic diseases, discrimination and stigma, total lack of access to social services, lack of identity papers and other categories of interrelated problems. Researches suggest that the phenomenon of homelessness has become acute in Romania, reaching at least its second proliferation wave, as some of the post-revolutionary homeless have given birth to offspring of their own, while the institutional capacity has been almost inexistent for a long time and it is still far insufficient, in conditions of uncertainty regarding the real size and nature of the phenomenon. Most of the intervention capacity is shaped as emergency response to crises situations. The "invisibility" of the phenomenon for the society has been increased by the lack of credible administrative data or research estimates. Interviews conducted by the author complement the scarce supply of recent literature on homelessness, in an attempt to bring this social problem into the focus of research and policy.

Keyword: homelessness, measurement method, social policy

\section{Defining homelessness}

Homelessness has been acknowledged by democratic societies as a major social problem quite recently, in the late 70s early 80s (Jencks, 1994; Dan, Serban \& Grigoras, 2008). The phenomenon was previously perceived as a marginal one, while the blame for living in the streets was put on the shoulders of the homeless, whom were believed to suffer from personal deficiencies obstructing their normal social integration pathway (Anderson, 1923; O'Connor, 1963; Wiseman, 1970; Cook, 1975; Digby, 1976). The concept of homelessness has gradually widened its significance in the last decades, from its initial meaning of rooflessness to a more comprehensive concept, including the dimensions of unsecure and improper housing (O'Sullivan, Busch-Geertsema, Quilgars \& Pleace, 2010). Currently, the European Typology on Homelessness and Housing Exclusion (ETHOS), developed through research of the European Observatory on Homelessness and adopted by the European Federation of National Organisations working with the Homeless (FEANTSA) is referenced in most European countries, and beyond, as the main conceptual tool in defining homelessness, although with various amendments from one study to another. Originally, the research team analyzed homelessness in the framework of three "domains" (Edgar, Doherty \& Meert, 2004), i.e. the physical one, which refers to the actual type of housing/living place, the legal domain and finally the social domain (as displayed in Table 1), and integrated in this analyses seven categories of homelessness: rooflessness, houselessness, insecure and inadequate housing, inadequate housing and social isolation within a legally occupied dwelling, inadequate housing and insecure housing. ETHOS was later developed from this model for operational purposes (Table 2) while an even more reduced and simplified version, called ETHOS LIGHT, refined further the conceptual model in order to respond to measurement concerns at the level of the EU countries. 
Although the definition derived from this theoretical approach constitutes the mainstream academic perspective of homelessness, and has reached also widespread consensus among policy-makers, the limitations at the level of measurement methods lead to research being confined to much narrower populations (less categories) than the ETHOS definition would require. For instance, the recommendations of the European Commission and Eurostat for the 2011 national censuses, which were envisaged to include homeless, referred only to the categories of "roofless" and part of the "houseless" in the ETHOS typology, ignoring all the other categories related rather with the risk of becoming homeless. The EC guidance (Baptista, Benjaminsen, Pleace \& Busch-Geertsema, 2012) highlighted the following categories: (i) rooflessness or primary homelessness, namely unsheltered persons living in the streets and (ii) persons with no regular accommodation or switching accommodations and person benefiting from residential services for the homeless. The recommendations proposed by the UNECE/EUROSTAT report for the 2010 census (United Nations, 2006) are also narrower than the EHOTS conceptual framework. The definition of homelessness refers to people sleeping rough or in buildings which were not designed for human habitation, in emergency centres, or night shelters, in emergency accommodation in hotels, guest houses or bed and breakfast, in hospitals due to a lack of decent shelter or in accommodation temporarily provided by friends or relatives because of the lack of a permanent place to stay. Most of the countries adopted for the censuses even narrower definition of homelessness: while sleeping in the streets or in emergency housing was widely considered, immigrants and institutionalized individuals with no accommodation available were ignored and some countries din not count the beneficiaries of longer-term services for the homeless (Baptista, Benjaminsen, Pleace \& Busch-Geertsema, 2012).

Despite delays in adopting ETHOS, national divergences at the theoretical level and differences in the capacity of the statistical systems to estimate homelessness, one could consider this definition as the main reference research-wise. Adopting it in various national contexts does not imply immediate commitment in reporting based on it; the concept of "intelligent segmentation" (Cordray, 1997) could be put to use, i.e. carrying on studies in the theoretical framework of ETHOS while reporting only components of the broad definition of homelessness in order to ensure consistency across countries.

\section{Research on homelessness}

The understanding of homelessness has shifted in recent years towards a more structural approach, with individual characteristics being considered as well in order to differentiate among various pathways to homelessness. Most of the research analyzes the phenomenon as a dynamic interaction between individual characteristics and structural change (Cloke, 2010), in the paradigm of what specialists have called the "new orthodoxism" in this domain (Pleace, 2010). This type of balanced approach has become popular with the 1995 research of Avramov who argued that homelessness is associated with monetary insufficiency and lack of access to housing but also triggered in many cases by individual traumatic events.

As in the case of poverty and social exclusion, homelessness needs to be understood in the light of the wider processes in the society and researched as a multidimensional process. The size and nature of homelessness is directly linked with housing policies in at least two ways: (i) the absence of housing policies or their progressive character is likely to boost the number of people becoming homeless (ii) the policies regarding social, transitory and emergency housing directly affect the capacity to alleviate homelessness. Some research (Barlow \& Duncun, 1994) has aimed to place housing policies in the wider framework of the welfare regimes developed by Esping-Anderson (1990). Barlow and Duncun identified an additional welfare regime to the liberal, corporatist and socialist democratic one in the original theoretical framework of Esping-Andersen, namely the category of rudimentary regimes, characterizing southern Europe, with limited or no intervention in the housing sector and more likely to promote self-help. The decreasing values of the indicators on social housing, correlated with the lack of other housing policies dedicated to the worst off, place Romania in the category of "rudimentary regimes". Research (Culhane \& Byrne, 2011) shows that housing vulnerability has increased in most of the European countries and worldwide during recent decades, as a result of the marketisation of the housing provision, decreased stock of public and social houses. Unemployment, low education and health problems are also strongly associated with the pathway to homelessness. However, less evidence is available on the effectiveness of these services for homeless.

Cross-sectional surveys tend to be the most widespread research methodology utilized in homelessness research. Yet, in the recent years great emphasis has been placed on the need for longitudinal studies in order to understand the pathways into homelessness and also the trajectories into and out of homelessness. In a recent study (Chamberlain \& Johnson 2011), the authors identify five ideal typical routs into adult homelessness: housing crises, family breakdown, substance abuse, 
mental health and young-to-adult. They also argue that people on different pathways deal differently with the fact that they belong to the homeless sub-culture. This dynamic analysis contributes to the understanding of why people on some pathways remain homeless for longer periods of time than others with a different personal history (Clapham, 2005).

\section{Quantifying the homeless}

Despite the rich corpus of literature on the issue of homelessness, quantifying the phenomenon remains an important challenge both at the theoretical level and in the practice of most of the countries carrying on systematic assessments of the phenomenon. In the USA, the authorities use snapshot counts in order to determine the size of the homeless population. The authorities (state level or municipality level) use a crosscheck survey including electronic administrative records for people in accommodation for homeless and street counts conducted by outreach workers and volunteers (Homeless Research Institute, 2014). Although variations are observed across communities and over time, it is the most reliable estimate of people experiencing homelessness in the United States. In the 2011 Census, European countries employed different methodologies for counting the homeless: headcounts were used in some of the countries, while in others daytime homeless services provided figures on people living in rough conditions; some countries distributed census questionnaires through NGOs while others combined this approach with direct counting; some countries used the same questionnaire for the homeless as for the general population while others used specific questionnaires.

Theoretically, there are three main instruments used to measure homelessness: (i) surveys, which can sample homeless population, housing needs or other aspects of the homelessness problem, (ii) registers: municipalities, NGOS or other types of services dedicated to homeless; (ii) censuses. In some approaches, the help of specialists is put to use in order to estimate the size of the population while others attempt to produce samples, which can be inferred for the overall population. The main methodological problem is that the homeless are an elusive population. One way to surpass the methodological difficulties and to minimize the costs of large sample surveys is to use the capture-recapture method (Fisher, Tuner, Pugh \& Taylor, 1994; Sudman, Sirken and Cowan 1988). The method consists of two or more consecutive or independent simultaneous counts used to infer the overall population from the difference observed in the captures. The method has its own limitations as it relies on a series of assumptions that are difficult to withhold in the case of homelessness, namely the homeless population should remain stable during the implementation of the survey, the probability should be the same for every member of the population and the captures should remain independent (Williams, 2010).

However, in order to find out if the phenomenon has a chronic character for a concentrated population or a temporary one for a wide population, longitudinal studies are required, using panel surveys or retrospective questions.

\section{Intervention models}

Worldwide, there are two main perspectives regarding the intervention models best suited for the homeless, (i) one advocating gradual assistance for the integration, starting with emergency health support and sheltering, continuing with transitional accommodation and various service provision and culminating with housing provision and labour market /social integration, and (ii) another perspective promoting the model of abrupt change and immediate access of homeless to more permanent residential solution. The first perspective might be labeled as the traditional thinking paradigm, or linear model of intervention, and was criticized as being too prescriptive in terms of imposing a model for social integration and housing sustainability. The second still struggles to persuade researchers of its merits and has benefited from the experience of limited pilot projects and programs, among which the best known is the Housing First, the USA based program offering permanent, affordable housing as quickly as possible for individuals and families experiencing homelessness, and then providing the supportive services in order to avoid return into homelessness. The three successive Housing First Programs have offered a substantial supply of housing units, have promoted client choice, have complemented housing with a wide range of supportive services like comprehensive mental health services, medication, as well as support for independent living skills and permanent care. Housing first models lead to higher rates of housing retention but are not equally successful in improving the condition of the beneficiaries in other areas like health or occupation and their generalization potential is contested as they involve high management costs (Groton, 2013). The gradual versus abrupt models of intervention has been also called the "staircase" versus "elevator" paradigms (Johnson \& Teixera, 2010).

Recent literature stresses out also that increased differentiation among various types of homeless people and homelessness histories requires increasing personalized support, since services can not be equally relevant for all beneficiaries. For instance, the provision of food, clothes, access to clean water and laundry facilities may be valuable for 
those with no accommodation while entitling homeless to a house may require a different type of services altogether. The growing importance of prevention measures (Pawson \& Munro, 2010) leads to an even larger array of measures and services for tackling homelessness. Table 3 offers both a brief account of the typical services employed for homeless people and the logic of intervention in a sequential manner, with ensuring an independent life as the final point. Another classification puts forward the following broad types of services (European Commission, 2007):

- Accommodation for homeless people - eg. emergency shelters, temporary hostels, supported or transitional housing

- $\quad$ Non-residential services for homeless people - eg. outreach services, day centres, advice services etc.

- Accommodation for other client groups that may be used by homeless people. eg. hotels, bed and breakfast, specialist support and residential care services for people with alcohol, drug or mental disorders

- Mainstream services for the general population that may be used by homeless people, eg. advice services, municipal services, health and social care services

- $\quad$ Specialist support services for other client groups that may be used by homeless people, eg. psychiatric counselling services, drug detoxification facilities.

One theoretical flaw of all the models of intervention is that they insufficiently deal with invisible /hidden homelessness. There are several evaluations stressing that homeless people often do not access or leave local authority offices without receiving meaningful advice and assistance $(X X X)$. It is not clear, for instance, to what extent a "hidden homelessness" is present in Romania, namely people who are not registered in the records of the police (and part of them will not appear in the records of the census as well) and may not even be listed in the records of the relevant NGOs.

The selection of beneficiaries for integration services - housing, employment, education and, in some degree, health services and counseling services - does not focus on the worst off the homeless but rather on the better off, regarded as having a higher potential for moving towards more independent living (Johnson \& Teixera, 2010).

\section{Homelessness in Romania}

Homelessness became chronic over the last two decades in the context of marginalization by policy makers, lack of research data and solid analysis. New mechanisms for the abandonment in the streets have emerged, like exiting the child protection system, restitution of nationalized houses or homelessness as a result of real estate scams. For other types of pathways into the streets, such as family breakdown or domestic violence, solutions for the prevention of homelessness have not been provided. Some studies talk about the emergence of a generation of children born in the streets (according with a 2014 Save the Children research, almost 1/3 of the adults living in the streets have a more than 10 years long history of homelessness - they are the former street children). Both the public welfare and NGOs have a reduced capacity to intervene on the issue, most often focused on emergency aid.

In Romania, there is a serious lack of statistically robust quantitative studies. The few studied carried on are not based on survey data with statistically representative samples. There have been several attempts to offer estimates of the size of homelessness in Romania, usually based on figures reported by the local authorities, with no real control of the researchers over the method used in this purpose by each municipality (Dan, 2007). A series of approximations carried on in 2007, using this type of research design, estimated a number ranged between 11,000 and 14,000 homeless at the national level. Other estimates, exclusively from administrative sources (Ministry of Regional Development and Public Administration, 2008), suggest a much lower figure, about 4,000 homeless people in the country in 2008 . While the census has collected information on homeless, with the help of the police as well, it is expected to return much lower estimates than the real situation, as it was done with the support of the coercive institutions and it was not designed specifically in the purpose of estimating homelessness.

Most homelessness is concentrated in large cities. An estimate for Bucharest widely quoted during the last 15 years has been issued by the Medicines sans Frontiers Romania (1998), - later on Samusocial -, using a type of count-recount procedure and refers to 5,000 homeless people only in the capital city. The registers of the same Samusocial NGO include more than 4,000 individual beneficiaries of the day care services for homeless in Bucharest since 1997.

There are no official figures on the number of children and young people living on the streets. In 2009, an estimate of the homeless children and youth in, Bucharest, Brasov and Constanta, three of the largest cities, has been released (Lazar \& Grigoras, 2009). The number of children and youth identified amounted to about 1,400. The vast majority of these children are in the capital city, more than 1,000. Less than half are children (0-17 years), most of them being young people aged 
18-35. Children and young people living with family and working on the street is only about one third in Bucharest, while in other cities this category is overwhelming. Effectively living on the streets for long periods of time seems to be a rather specific situation for the children and youth in the capital city.

Various estimates show that the vast majority of homeless people, i.e. more than $80 \%$, are men, which is consistent with findings in other countries. The level of education is low: almost half have completed at most lower secondary schools and vocational schools. A large part of homeless have medical problems but access to health services is low. In the 2008 research (Dan, 2008), post-institutionalized children and youth were among the largest group of homeless along with children exiting the system (23.4\%). A common homelessness trigger were family events such as divorce, separation, arguing with family members, parental abandonment, evacuation by the family of the husband / wife after the death or expulsion of a family member (29.2\%). Selling the house and spending money afterwards was also a quite prevalent situation (15.3\%). Other mechanisms more often mentioned for the loss of the house were the restitution of nationalized houses and dispossession by scam (about $5 \%$ each). One can distinguish two main categories: (i) young people exiting the institutions of the special child protection system and (ii) individuals/ families in the streets as result of a major negative personal or family event or direct loss of the house.

Life on the street is associated with serious health problems, chronic malnutrition, school dropout and illiteracy (about $50 \%$ ), physical abuse and sexual abuse (usually beginning in the family and continued in the streets), stigma and discrimination, limited access to social services (education, health, social assistance), use of drugs or chemical solvents (Dan, 2008). Among homeless, chronic diseases and mental illnesses are more common than among the overall population. Homeless people have sporadic access to food and water. Lack of identity papers is a common problem. The prospect of employment or even work by the day and is very low due to poor hygiene and social networking capabilities. Research has consistently shown that homelessness often has detrimental effects on both physical and mental health and well-being. There is also evidence that the life expectancy of single homeless people may be significantly less than people who have never experienced homelessness.

The in-depth interviews conducted over 6 months in 2013 by the author with 23 homeless people receiving the support services of the Samusocial center revealed that:

-Many of the interviewees come from residential centers or from socially disorganized families

-For the interviewees growing up in families with no major social vulnerability, there is one crucial event triggering the trajectory leading to homelessness: sickness, divorce, loosing the house as a result of the restitution of the nationalized dwellings, scamming with houses etc.

-The better off layer of the homeless population, i.e. those accessing on regular basis the scarce offer of social services dedicated to this social category, usually resent night shelters and access them only as last resort facilities, on account of reported violence and thievery

-Even the "better off" more active homeless population does not access social services they are entitled to, such as social aids, free of charge health services, pensions etc.; even though these are individuals who manage to restrain a certain degree of social autonomy, as a result of small occasional incomes and relying on NGO support, they do not equally profit from the mainstream social services

-All the interviewees declared that it is impossible for them to find steady formal type of work; this finding is also supported by the fact that the representatives of the NGO hosting the discussions were able to identify only a few cases of successful labour market integration among their beneficiaries over time a long period of time $-5-10$ years; this is to be interpreted with caution, as the Samusocial workers were fully aware only of the beneficiaries with whom they had a closer and repeated collaboration; the number of successful employment stories might be slightly higher among the thousands of people accessing the NGO services over time

-There is a widespread sense of personal freedom, which more integrated citizens might label as misperceived "freedom" which the homeless associate with their "lifestyle" and which is an important challenge for any intervention model

-Homeless people who are not in the streets stay in temporary accommodation - night shelters, private entrepreneurship initiatives for the accommodation of poor population, hostels, shared rent in low value areas such as ghettoes - as long as possible in the absence of more long-term residence; there is a tendency for this shelters and other transitional services to become almost permanent accommodation

-Some of the homeless people have experienced emigration episodes - contribution of remigration to homelessness in the recent years might be a valuable research topic for the future 
The "Survey of defining socio-demographic indicators of the homeless people" (Badea, 2008), in which the content of the Samusocial files of 1054 homeless was evaluated during three years - $2006-2008)$, found that:

$-73 \%$ ( 770 cases) of the respondents are male and $27 \%$ (284 cases) were female.

$-69 \%$ (727 cases) of the subjects had their last home in Bucharest and 31\% (327 cases) of them are from other localities.

$-52 \%$ of the analyzed group is the people in the age range $30-49$ years ( $30-39$ years - $24 \%$ and $40-49$ years - $28 \%$ ).

$-65 \%$ (680 cases) of the subjects did not have identity documents, being practically unable to access certain minimum rights of social protection (social dining, income support, health care).

-A wide range of options are used as overnight accommodation venues, the most important being: staircases - $19 \%$ improvised shelters - $18 \%$ regularly hosted knowledge - $12 \%$, stations - $9 \%$, parks - $8 \%$.

-The main financial sources of income are the occasional (undocumented labor, "black"), begging - $12 \%$ pension - $9 \%$. There are people who say they have no source of income $-13 \%$ and $2 \%$ of subjects (16 cases in 1054) said they are lawfully employed and have a monthly salary.

$-37 \%$ of subjects had secondary education and the same percentage is also found for those with primary education

While homelessness has become chronic, solutions are scarce. For instance, at the level of the country, there are only 14 available services for homeless children and youth (day-care centers, day and night shelters) with a capacity of 142 places, located in several cities: Brasov, Cluj, Bucuresti, Alba-Iulia, Constanta, Arad, Galați.

\section{Areas for improvement in Romania}

Policies and research related to homelessness in Romania are critically underdeveloped. In the first post-communist years, the novelty of the phenomenon and the relatively low number of individuals living in the streets have contributed to the marginal interest shown by the decision-makers in the alleviation of the problem. Not much improvement has been achieved since, despite the considerably larger incidence reached by the phenomenon.

\section{Research}

Assessing homelessness at the national level and in major cities is needed, in order to start shaping adequate policies. Although homelessness is elusive to measuring, comprehensive information systems can be built on multiple data sets, extracted from registries and surveys. Creating a system for recording and monitoring homelessness requires collaboration between public institutions and NGOs. In Romania, for the moment, solid data sources are lacking on all these areas.

Thematic surveys should provide estimates of the number of homelessness and types of homelessness, causes and effects of the phenomenon as well as needs and opportunities for social reintegration.

Dedicated indicators built into monitoring systems at the national level, such as the national social inclusion indicators dataset (Briciu \& Grigoras, 2004) has, depend on the availability of data. Research has to provide also a more rigorous answer on the causes of homelessness in Romania, in order to understand which social groups are at risk. Special monitoring indicators should be developed in the area of risk prevention, e.g. the share of poor population spending more than half of the income on housing or share of large overcrowded households with distant relatives and non-family members.

\section{Policies}

Homeless people live on the edge of survival, with their fundamental right to life threatened on daily basis. This situation should call for action. The problem of homelessness has reached a critical level due to the combination of its chronic aspect and prolonged lack of adequate support. It is expected that in recent years, during the economic crisis, a higher number of people were thrown into the streets (Samusocial, 2013). The emergency response has an insufficient coverage, in terms of food or emergency shelter, at least in the cold periods of the year (e.g. in Bucharest there are around 1,000 places in shelter while most of the estimates indicate a larger number of homeless). Integrated interventions aimed at long-term social reintegration of homeless are rare, even in the NGO sector, and address a very limited group of beneficiaries. At the 
same time, there are no programs to prevent the loss of houses by people in extreme poverty or living in dysfunctional families.

A national strategy on homelessness should be developed in order to define the main objectives, like eradication of child homelessness, minimization of the numbers of entries into the homeless condition, granting of full emergency services, reintegration and housing policies in the area and so on. The overall goal should be to build a coordinated system for providing minimum support (food, emergency shelter, medical assistance) while developing response capabilities for social reintegration and early prevention. The anti-homelessness policies should be integrated across strategies and social policies initiated by the Romanian Government; an integrated institutional framework for intervention should be prepared.

Such a strategy should define the baseline situation and establish a monitoring system. Policies can be roughly classified in two categories: (i) policies designed for the prevention of risks, which are missing in the Romanian policy framework and (ii) policies for the alleviation of the phenomenon, which are massively under-developed. In the category of prevention, several types of interventions could be shaped using the limited amount of information already available on the mechanisms of falling in homelessness:

-Cessation of evictions, many of them illegally carried on in the past and without the will or the capacity of the local authorities to compensate the people in question with social housing programs, as required by the legal provisions

-Sustainable solutions for the people at high risk of losing the dwelling: people with no incomes and with high level of arrears for the housing maintenance

-A more responsible inventory and control of the illegal and improper settlements, with compensation measures available in the interest of the people inhabiting them

-Housing solution, integrated in a wider package of social services for activation, for the people leaving institutions like prisons, child-care residencies, asylums, hospitals

-Tackling social pathologies like addictions, juvenile delinquency, domestic violence, insufficiently addressed by the policies at the moment (Child's Protection National Strategy, 2014) and acknowledged in the literature to be some of the most frequent triggers of homelessness, should be carried on with a special attention of the residential status of the people affected by these phenomena

-A stock of emergency social houses has to be available for the people who recently lost their dwellings in order to prevent consolidation of homelessness

-Other areas of policy, like health, education, national and international migration policies or displacements policies have to streamlined with anti-homelessness policies

-Support for vulnerable lonely people, such as the elderly, the physically and psychologically impaired, against frauds and cheating

-In periods of crises, such as the economic breakdown recently occurred, policies should be especially concern with the dynamic of homelessness is often described considered a lagging phenomenon, i.e. it takes time for economic and housing trends to impact trends in homelessness

As far as the alleviation component is concerned, a step-by-step intervention plan would be needed at the national level in order to gradually move from emergency services to long-term integration programs. Services could be classified as emergency services (food, shelter, medical assistance, shelter), short-term services (issuing identity cards, re-entitlement to certain rights such as social assistance benefits, rehab services, reconnection with family members and friends) and long-term (housing, education, employment). Merely granting a shelter / a house creates another poverty trap, as proved by various places in Romania where granting social housing transformed the former homeless in residents permanently menaced with evictions on the grounds of unpaid utilities.

A special effort should be made in order to bring in the attention of the collectivity the phenomenon, gain public support and advocate for the abandonment of harmful practices (begging). The range of actions could cover:

-Increasing the capacity of intervention in the street to meet the basic needs for food and medical assistance

-Creating a network of shelters and emergency housing so that fully covers the needs especially during periods with low temperature values

-Developing of program for social reintegration 
-Correlating the services dedicated to homeless in an integrated package: identification and registry, health care, social assistance (allowances), access to pensions, access to shelters and housing, access to education, access to employment opportunities.

-Increasing access of homeless to legal rights provided by laws such as the guaranteed minimum income, social exclusion law, the law of social economy and other legislative provisions deeming the homeless among eligible beneficiaries

Eradication of the homelessness of children should be a top priority in any kind of scenario for intervention.

In the area of housing policies, a reform should be launched. The construction of social houses practically collapsed after 1990 as a result of the massive withdrawal of state from its function of welfare provider. One could estimate that housing were cut down more severely than other social services. While in the 1998-2007 interval around 2,000 social were built per year, in the 2010-2013 only around 200 units were still built. This collapse was registered amid the falling of all types of housing policies.

\section{References}

Anderson, N. (1923), The Hobo; The Sociology of the Homeless Man. The University of Chicago Press

Avramov, D. (1995). Homelessness in the European Union. FEANTSA, Brussels

Baptista, I, Benjaminsen, L., Pleace, N. \& and Busch-Geertsema, V. (2012). Counting Homeless People in the 2011 Housing and Population Census. Brussels: European Observatory on Homelessness

Briciu, C. \& Grigoraş, V., National system of social inclusion indicators, World Bank, 2005

Busch-Geertsema, V., Edgar, W., O'Sullivan, E. \& Pleace, N. (2010). Homelessness and Homeless Policies in Europe: Lessons from Research. Brussels: FEANTSA

Chamberlain, C. \& Johnson, G (2011), Pathways into adult homelessness ( pp. 60-77). In Journal of Sociology, March 2013; vol. 49, 1

Clapham, D. (2005) The Meaning of Housing: A Pathways Approach. Bristol: The Policy Press

Cloke, P., May, J. \& Johnsen, S. (2010) Swept up lives? Re-envisioning the Homeless City Chichester, UK: Wiley-Blackwell

Conference of European statisticians, (2006). Recommendations for the 2010 Censuses of Population and Housing, prepared in cooperation with the Statistical Office of the European Communities (eurostat). United Nations Publications

Cook, T. (1975). Vagrant Alcoholics. London: Routledge \& Kegan Paul.

Cordray, D. S. (2007), Critical Issues in Counting Homeless Persons, What's Behind the Numbers? Definitional Issues in Counting the Homeless, in Understanding Homelessness: New Policy and Research Perspectives. Fannie Mae Foundation

Culhane, D. P. \& Byrne, T. (2011). Homelessness and Housing Exclusion in Europe: Challenges and Opportunities for Research and Policy. Homelessness Research in Europe: Festschrift for Bill Edgar and Joe Doherty. Brussels: FEANTSA

Dan, A. \& Dan, M., The Homeless in Romania - an estimation of their number . In Quality of life Research Review No. 3$4 / 2004$

Dan, A. (2006) Housing policies: Romania, where to? A comparative analyses of Romania in the EC and EU context. Bucharest University Publishing

Edgar, B. (2009). Counting the Homeless - Improving the Basis for Planning Assistance, Peer Review. in Social Protectionand Social Inclusion European Housing Research Ltd. Vienna: DG Employment, Social Affairs and Equal Opportunities

Edgar, B, Doherty, J. \& Meert, H (2004). Immigration and homelessness in Europe (Feantsa S), Paperback. Policy Press

Esping-Anderson, G. (1990), The Three Worlds of Welfare Capitalism. Princeton University Press 
Eoin O., Busch-Geertsema, V., Quilgars D. \& and Pleace, N. (2010). Homelessness Research in Europe. Brussels: FEANTSA

Fisher N, Turner SW, Pugh R \& Taylor C. (1994). Estimating numbers of homeless and homeless mentally ill people in north east Westminster by using capture-recapture analysis. BMJ

Gradinaru, C. (2014). Assessment of the Street Children and Youth". Save the Children, Romania

Groton, D (2013). Are Housing First Programs Effective?, A Research Note. Florida State University, College of Social Work,Journal of Sociology \& Social Welfare, March 2013, Volume XL, Number 1 (pp. 51-63)

Jencks, C. (1944). The Homeless. Harvard University Press

Johnsen, S \& Teixeira, L (2010). Staircases, Elevators and Cycles of Change - 'Housing First' and Other Housing Models for Homeless People with Complex Support Needs. The University of York, Crises

O'Connor, P. (1963). Britain in the Sixties: Vagrancy. London: Penguin

Measurement of Homelessness at EU level (2007). European Commission, DG Employment, Social Affairs and Equal Opportunities

Pleace, N. (2000) The New Consensus, the Old Consensus and the Provision of Services for People Sleeping Rough, (pp.581-594). Housing Studies 15(4).

Sudman S, Sirken MG \& Cowan, CD. (1988) Sampling rare and elusive populations. Science.

The State of Homelessness in America (2014). Homelessness Research Institute

Williams, M, (2010). Can We Measure Homelessness? A critical evaluation of "Capture-recapture". Methodological Innovations Online. Cardiff University School of Social Sciences

Wiseman, J. (1970). Stations of the lost: the treatment of skid row alcoholics. Englewood Cliffs: Prentice Hall

\section{Tables}

Table 1. Seven theoretical categories of homelessness

\begin{tabular}{|c|c|c|c|c|}
\hline $\begin{array}{l}\text { Conceptual } \\
\text { category }\end{array}$ & Operational category & Physical domain & Legal domain & Social domain \\
\hline \multirow[t]{2}{*}{ Homelessness } & 1. Rooflessness & No dwelling (roof) & $\begin{array}{l}\text { No legal title to a } \\
\text { space for exclusive } \\
\text { possession }\end{array}$ & $\begin{array}{l}\text { No private and safe } \\
\text { personal space for } \\
\text { social relations }\end{array}$ \\
\hline & 2. Houselessness & $\begin{array}{l}\text { Has a place to live, fit } \\
\text { for habitation }\end{array}$ & $\begin{array}{l}\text { No legal title to a } \\
\text { space for exclusive } \\
\text { possession }\end{array}$ & $\begin{array}{l}\text { No private and safe } \\
\text { personal space for } \\
\text { social relations }\end{array}$ \\
\hline \multirow[t]{4}{*}{$\begin{array}{l}\text { Housing } \\
\text { exclusion }\end{array}$} & $\begin{array}{l}\text { 3. Insecure and inadequate } \\
\text { housing }\end{array}$ & $\begin{array}{l}\text { Has a place to live (not } \\
\text { secure and unfit for } \\
\text { habitation) }\end{array}$ & No security of tenure & $\begin{array}{l}\text { Has space for social } \\
\text { relations }\end{array}$ \\
\hline & $\begin{array}{l}\text { 4. Inadequate housing and } \\
\text { social isolation within a } \\
\text { legally occupied dwelling }\end{array}$ & $\begin{array}{l}\text { Inadequate dwelling } \\
\text { (unfit for habitation) }\end{array}$ & $\begin{array}{l}\text { Has legal title and/or } \\
\text { security of tenure }\end{array}$ & $\begin{array}{l}\text { No private and safe } \\
\text { personal space for } \\
\text { social relations }\end{array}$ \\
\hline & $\begin{array}{l}\text { 5. Inadequate housing } \\
\text { (secure tenure) }\end{array}$ & $\begin{array}{l}\text { Inadequate dwelling } \\
\text { (dwelling unfit for } \\
\text { habitation) }\end{array}$ & $\begin{array}{l}\text { Has legal title and/or } \\
\text { security of tenure }\end{array}$ & $\begin{array}{l}\text { Has space for social } \\
\text { relations }\end{array}$ \\
\hline & $\begin{array}{l}\text { 6. Insecure housing } \\
\text { (adequate housing) }\end{array}$ & Has a place to live & No security of tenure & $\begin{array}{l}\text { Has space for social } \\
\text { relations }\end{array}$ \\
\hline
\end{tabular}




\begin{tabular}{|l|l|l|l|l|}
\hline & $\begin{array}{l}\text { 7. Social isolation within a } \\
\text { secure and adequate } \\
\text { context }\end{array}$ & Has a place to live & $\begin{array}{l}\text { Has legal title and/or } \\
\text { security of tenure }\end{array}$ & $\begin{array}{l}\text { No private and safe } \\
\text { personal space for } \\
\text { social relations }\end{array}$ \\
\hline
\end{tabular}

Source: Edgar, 2004

Table 2. ETHOS - European typology on homelessness and housing exclusion

\begin{tabular}{|c|c|c|}
\hline Conceptual category & Operational category & Living situation \\
\hline \multirow[t]{2}{*}{ ROOFLESS } & 1 People living rough & 1.1 Public space or external space \\
\hline & 2 People staying in a night shelter & 2.1 Night shelter \\
\hline \multirow[t]{5}{*}{ HOUSELESS } & $\begin{array}{l}3 \text { People in accommodation for the } \\
\text { homeless }\end{array}$ & $\begin{array}{l}\text { 3.1 Homeless hostel } \\
\text { 3.2 Temporary accommodation } \\
\text { 3.3 Transitional supported accommodation }\end{array}$ \\
\hline & 4 People in a women's shelter & 4.1 Women's shelter accommodation \\
\hline & $\begin{array}{l}5 \text { People in accommodation for } \\
\text { immigrants }\end{array}$ & $\begin{array}{l}\text { 5.1 Temporary accommodation, reception centres } \\
\text { 5.2 Migrant workers' accommodation }\end{array}$ \\
\hline & $\begin{array}{l}6 \text { People due to be released from } \\
\text { institutions }\end{array}$ & $\begin{array}{l}\text { 6.1 Penal institutions } \\
6.2 \text { Medical institutions } \\
6.3 \text { Children's institutions/homes }\end{array}$ \\
\hline & $\begin{array}{ll}7 & \text { People receiving longer-term } \\
\text { support (due to homelessness) }\end{array}$ & $\begin{array}{l}\text { 7.1 Residential care for older homeless people } \\
7.2 \text { Supported accommodation for formerly } \\
\text { homeless persons }\end{array}$ \\
\hline \multirow[t]{3}{*}{ INSECURE } & $\begin{array}{l}8 \text { People living in insecure } \\
\text { accommodation }\end{array}$ & $\begin{array}{l}\text { 8.1 Temporarily with family/friends } \\
8.2 \text { No legal (sub)tenancy } \\
8.3 \text { Illegal occupation of land }\end{array}$ \\
\hline & 9 People living under threat of eviction & $\begin{array}{l}\text { 9.1 Legal orders enforced (rented) } \\
\text { 9.2 Repossession orders (owned) }\end{array}$ \\
\hline & $\begin{array}{l}10 \text { People living under threat of } \\
\text { violence }\end{array}$ & 10.1 Police recorded incidents \\
\hline \multirow[t]{3}{*}{ INADEQUATE } & $\begin{array}{l}11 \text { People living in temporary/non- } \\
\text { conventional structures }\end{array}$ & $\begin{array}{l}\text { 11.1 Mobile homes } \\
\text { 11.2 Non-conventional building } \\
\text { 11.3 Temporary structure }\end{array}$ \\
\hline & 12 People living in unfit housing & 12.1 Occupied dwelling unfit for habitation \\
\hline & $\begin{array}{l}13 \text { People living in extreme } \\
\text { overcrowding }\end{array}$ & 13.1 Highest national norm of overcrowding \\
\hline
\end{tabular}

Source: Edgar, 2009, p.73

Table 3. Harmonised Definition of Homelessness - European Commission

Operational Category

Living Situation

Definition 


\begin{tabular}{|c|c|c|}
\hline People Living Rough & $\begin{array}{l}\text { Public space / external } \\
\text { space }\end{array}$ & $\begin{array}{l}\text { Living in the streets or public spaces without a } \\
\text { shelter that can be defined as living quarters }\end{array}$ \\
\hline $\begin{array}{l}\text { People in emergency } \\
\text { accommodation }\end{array}$ & Overnight Shelters & $\begin{array}{l}\text { People with no place of usual residence who } \\
\text { move frequently between various types of } \\
\text { accommodation }\end{array}$ \\
\hline $\begin{array}{l}\text { People living in } \\
\text { accommodation for the } \\
\text { homeless }\end{array}$ & $\begin{array}{l}\text { Homeless Hostels } \\
\text { Temporary Accommodation } \\
\text { Transitional Supported } \\
\text { Accommodation } \\
\text { Women's shelter or } \\
\text { refuge accommodation }\end{array}$ & $\begin{array}{l}\text { Where the period of stay is less than one } \\
\text { year }\end{array}$ \\
\hline $\begin{array}{l}\text { People living in } \\
\text { institutions }\end{array}$ & $\begin{array}{l}\text { Health care institutions } \\
\text { No housing available prior to } \\
\text { Release }\end{array}$ & $\begin{array}{l}\text { Stay longer than needed due to lack of } \\
\text { housing }\end{array}$ \\
\hline $\begin{array}{l}\text { People living in nonconventional } \\
\text { dwellings due to lack of housing }\end{array}$ & $\begin{array}{l}\text { Mobile homes } \\
\text { Nonstandard } \\
\text { building } \\
\text { Temporary structure }\end{array}$ & $\begin{array}{l}\text { Where the accommodation is used due to a lack } \\
\text { of housing and is not the person's usual place of } \\
\text { residence }\end{array}$ \\
\hline $\begin{array}{l}\text { Homeless people living } \\
\text { temporarily in conventional housing } \\
\text { with family and friends (due to lack of } \\
\text { housing) }\end{array}$ & $\begin{array}{l}\text { Conventional housing, but } \\
\text { not the person's usual } \\
\text { place of residence }\end{array}$ & $\begin{array}{l}\text { Where the accommodation is used due to a lack } \\
\text { of housing and is not the person's usual place of } \\
\text { residence }\end{array}$ \\
\hline
\end{tabular}

Source: European Commission, 2007 